\title{
SEBARAN SITUS PRA SRIWIJAYA DI RAWA PASANG SURUT: KAJIAN ARKEOLOGI RUANG DI KAWASAN KARANGAGUNG TENGAH, SUMATERA SELATAN
}

\section{DISTRIBUTION OF PRE-SRIVIJAYAN SITES ON TIDAL SWAMP: STUDY OF SPATIAL ARCHAEOLOGY IN KARANGAGUNG TENGAH, SOUTH SUMATRA}

\author{
Nurhadi Rangkuti \\ Balai Arkeologi Palembang \\ nurhadirangkuti@yahoo.com
}

\begin{abstract}
Archaeological research can not be separated from the three dimensions of archeology: form, space and time. Spatial dimension is essential in archeology that covers all phases of archaeological research (theory, method, practice). Collection, analysis, interpretation and presentation of archaeological data should be actively and creatively covered in the dimension of space, was realized in the form of a map. In the development of the map are integrated with other graphical data and databases, known as Geographic Information System. Study of spatial Archaeology in Karangagung Tengah conducted to determine the distribution pattern of the site and what factors influence the formation of the pattern. Archaeological sites scattered in the edges of tidal rivers with access to the Lalan River and Sembilang River which empties into the Strait of Bangka. Distribution of these sites mapped to the benefit of further research and reference to delineate the Karangagung Tengah zoning for conservation purposes.
\end{abstract}

Keywords: Spatial archaeology, Geographic Information System, Karangagung Tengah, Distribution pattern

\section{ABSTRAK}

Penelitian arkeologi tidak dapat dilepaskan dari tiga dimensi arkeologi, yaitu dimensi bentuk (formal), ruang (spatial) dan waktu (temporal). Dimensi ruang merupakan hal yang pokok dalam arkeologi yang mencakup seluruh tahapan penelitian arkeologi (teori,metode, praktek). Pengumpulan, analisis, penafsiran dan penyajian data arkeologi harus secara aktif dan kreatif tercakup dalam dimensi ruang, antara lain diwujudkan dalam bentuk peta. Dalam perkembangannya peta diintegrasikan dengan data grafis lainnya dan database, dikenal sebagai Sistem Informasi Geografis (Geographic Information System). Kajian arkeologi ruang di Kawasan Karangagung Tengah dilakukan untuk mengetahui pola sebaran situs dan faktor-faktor apa yang berpengaruh pada terbentuknya pola tersebut. Situs-situs arkeologi tersebar pada tepi anak-anak sungai pasang surut yang memiliki akses ke sungai Lalan dan Sungai Sembilang yang bermuara ke Selat Bangka. Persebaran situs-situs tersebut dipetakan untuk kepentingan penelitian lebih lanjut dan acuan untuk mendelineasi zonasi kawasan Karangagung Tengah untuk kepentingan pelestarian.

Kata kunci: Arkeologi ruang, Sistem Informasi Geografis, Karangagung Tengah, Pola distribusi

\footnotetext{
Tanggal masuk : 9 Maret 2014

Tanggal diterima : 5 Mei 2014
} 


\section{PENDAHULUAN}

Serangkaian penelitian arkeologi di Kawasan Karangagung Tengah, 栾@ Kecamatan Lalan, Kabupaten Musi Banyuasin, Sumatera Selatan, bermula dari laporan seorang kepala desa di kawasan tersebut pada tahun 1996. Kepala Desa Karangtirta di Karangagung Tengah melaporkan sejumlah manikmanik bahan kaca dan emas serta pecahan-pecahan tembikar berhias di Tanah Abang yang ditemukan melalui penggalian liar (Tri Marhaeni 2005, 2). Pada tahun 2000 Tim Balai Arkeologi Palembang mengadakan survei di Tanah Abang, letaknya di tepi Sungai Sembilang. Pada saat survei tim menemukan situssitus arkeologi di Karangagung Tengah, yang merupakan wilayah permukiman transmigrasi. Lokasi kawasan tersebut berada di sebelah selatan Tanah Abang.

Penelitian dengan melakukan survei dan penggalian arkeologis di Kawasan Karangagung Tengah dilakukan sejak tahun 2001 sampai 2006, kemudian dilanjutkan pada tahun 2010 dan 2014 dengan survei yang meluas sampai ke kawasan Taman Nasional Sembilang. Situs-situs arkeologis di kawasan Karangagung Tengah tersebar pada sungai-sungai kecil yang kini tinggal jejak alurnya saja, karena dibangunnya jalurjalur sungai buatan sejak tahun 1983 untuk mengalihkan air yang menggenangi rawa sekaligus untuk prasarana transportasi air. Situs-situs arkeologis ditemukan di Desa Mulya Agung, Desa Karyamukti, Desa Bumiagung, Desa Karangmukti, Desa Sari Agung, Desa Sukajadi, Desa Bumiagung dan Desa Purwo Agung.

Tinggalan arkeologis yang ditemukan meliputi benda-benda dari bahan organik dan bahan non organi. Benda-benda dari bahan organik yang ditemukan berupa kemudi perahu dari kayu, tulang-tulang dan gigi hewan, tempurung kelapa dan fosil kayu. Artefakartefak dari bahan organik meliputi gerabah, batu asah, manik-manik bahan kaca dan batu, anting dari timah dan perunggu, gelang perunggu dan cincin emas.
Tiang-tiang rumah kayu kuno ditemukan dalam penggalian arkeologis di Situs Mulya Agung. Tiang-tiang utama dibuat dari batang pohon yang dipangkas dan diruncingkan ujungnya dengan alat potong dari logam. Tiang-tiang kayu tersebut memiliki pertanggalan 1629 1624 BP (abad II-IV) dari hasil analisis radiocarbon (C14) liar (Tri Marhaeni 2005, 2). Hal ini menunjukkan situs-situs di Karangagung Tengah dari masa sebelum munculnya Sriwijaya di Sumatera.

Persebaran situs-situs hunian di Karangagung Tengah perlu dikaji lebih lanjut untuk mengenali pola dan mengapa terbentuk pola tertentu di kawasan situs tersebut. Pengenalan pola persebaran situs erat kaitannya dengan kondisi lingkungan dan kebudayaan pada masa itu. Sebagaimana diketahui, ada tiga dimensi arkeologi yaitu bentuk (form), ruang (space) dan waktu (time) yang menjadi landasan penelitian arkeologi. Dimensi ruang merupakan hal yang pokok dalam arkeologi yang mencakup seluruh tahapan penelitian arkeologi (teori, metode, praktek). Pengumpulan, analisis, penafsiran dan penyajian data arkeologi harus secara aktif dan kreatif tercakup dalam dimensi ruang (Green 1990, 3).

Masalah-masalah yang akan dijawab dalam kajian kali ini berkenaan dengan lokasi dan persebaran situs arkeologi pada kawasan Karangagung Tengah. Sebagaimana diketahui kawasan permukiman kuna tersebut berada di daerah rawa gambut yang mengalami pasang surut air laut. Pertanyaanpertanyaan penelitian yang diajukan adalah :

1. Bagaimana pola sebaran situs arkeologi yang menggambarkan pola pemukiman masyarakat pra Sriwijaya di Karangagung Tengah?

2. Faktor-faktor apakah yang mempengarui penentuan lokasi permukiman dan terbentuknya pola permukiman tersebut?

Tujuan penelitian ini adalah untuk menjelaskan dan memahami terbentuknya permukiman masa pra Sriwijaya didaerah rawa pasang surut. Persebaran situs terkait dengan lingkungannya dikaji dengan pendekatan arkeologi-ruang yang tersaji dalam bentuk peta. Dalam peta 
digambarkan persebaran situs dan zonasinya yang berguna untuk kepentingan pelestarian cagar budaya di daerah rawa pasang surut. Selama ini belum ada model pemintakatan (zoning) situs dan kawasan di daerah pasang surut.

\section{KERANGKA TEORI}

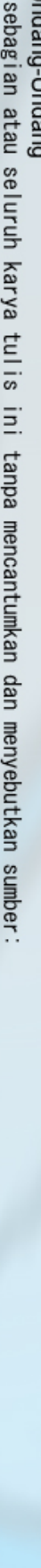

Dalam arkeologi, konsep settlement archaeology dan settlement pattern dipakai secara sistematis untuk pertama kali terhadap bukti-bukti arkeologis oleh Gordon Willey pada tahun 1953 dalam penelitian di kawasan situs Lembah Viru, Peru, yaitu:

"the way in which man, disposed himself over the landscape on which he lived. It refers to dwellings to their arrangement, and to the nature and disposition of other buildings settlement reflects the natural environment, the level technology on which the builders operated, and various institutions of social interaction and control which the culture maintained" (Willey 1953:2).

Willey menyatakan bahwa kajian pola permukiman merupakan studi mengenai cara yang dilakukan manusia untuk menata dirinya sendiri pada bentang lahan sebagai tempat manusia hidup. Hal itu tercermin dalam permukiman dan penataannya, dan ciri serta penempatan bangunan-bangunan lain yang berhubungan dengan kehidupan komunitas. Permukiman merupakan refleksi keadaan lingkungan alam, tingkat teknologi yang digunakan oleh pembangun permukiman, dan berbagai pranata interaksi dan kontrol sosial yang dipertahankan oleh kebudayaan.

Hasil penelitian arkeologi sebelumnya di Kawasan Karangagung Tengah telah berupaya menjelaskan pola pemukiman dan organisasi sosial-ekonomi masa pra Sriwijaya. Tri Marhaeni (2005, 67-69) menjelaskan bahwa permukiman kuno tersebut terdiri atas perkampunganperkampungan yang berpola menyebar pertaining to community life. The (dispersed pattern). Lebih lanjut Tri Marhaeni berangggapan ada perkampungan-perkampungan yang berpola memanjang mengikuti garis aliran sungai yang menghubungkan perkampungan di Karyamukti dan Mulyaagung.

Dalam penelitian arkeologi-ruang (spatial archaeology), David L. Clarke (1977) menetapkan tiga tingkatan ruang, yaitu mikro, semi-mikro dan makro. Tingkat-tingkat ruang ini ditentukan oleh peneliti (arbitrary) disesuaikan dengan kerangka teori yang digunakannya dalam penelitian.

Penelitian arkeologi ruang di kawasan Karangagung Tengah merupakan kajian ruang tingkat makro. Pada kajian tingkat makro dikaji sebaran dan hubungan antar situs dan lingkungannya pada satu wilayah yang telah ditentukan batas-batasnya melalui kriteria-kriteria tertentu. Dalam kajian ini digunakan konsep "landscape archaeology". Di Indonesia konsep ini disebut dengan istilah "arkeologi bentanglahan" (Rangkuti 1996) dan "arkeologi lansekap" (Susetyo 2007). Konsep "landscape" diadopsi dari konsep geografi. Menurut A.P.A Vink $(1983,2)$ istilah landscape digunakan untuk: (a) permukaan bumi dengan seluruh fenomenanya, meliputi ciri-ciri bentuk lahan (landform), vegetasi, dan ciri-ciri yang dipengaruhi oleh aktivitas manusia; (b) wilayah (region), yaitu daerah di muka bumi yang ditetapkan dan didelineasi berdasarkan ciri-ciri spesifik bentuk lahan, vegetasi dan juga ciri-ciri buatan manusia. Ciri-ciri spesifik tersebut membedakan suatu bagian permukaan bumi dari bagian lain.

Bintarto (1991, 5;12-13) menyatakan landscape atau bentang lahan meliputi bentang fisik (physical landscape), bentang budaya (cultural landscape) dan bentang sosial (social landscape). Bentang fisik atau ruang fisik merupakan suatu wadah dari berbagai sistem kehidupan dan komponen-komponen alam dan non-alam. Bentang budaya atau lingkungan binaan merupakan ujud bentanglahan sebagai akibat dari suatu interaksi antara manusia dengan wilayahnya, misalnya daerah pedesaan, 
I

() $p$

daerah perkotaan, atau bentang artefak lainnya. Bentang sosial adalah ujud kehidupan penduduk di muka bumi yang mencerminkan tingkat adaptasi atau persepsi penduduk terhadap lingkungannya. Bentang sosial merupakan zona-zona yang lebih menggambarkan pada struktur sosial-ekonomi penduduk.

Berdasarkan konsep "landscape" dalam geografi tersebut muncul konsep atau pendekatan "landscape archaeology" yang dikembangkan dalam buku Interpreting Space: GIS and Archaeology (1990) oleh Stanton W Green, Crumley dan Marquardt. "Landscape archaeology" atau "arkeologi bentanglahan" pada hakekatnya mengkaji ujud dan proses bentang budaya masa lalu dalam ruang dan waktu. Studi tersebut dilakukan dengan cara menganalisis hubungan antara data arkeologis dan data lingkungan dalam skala wilayah (Rangkuti 1996, 66).

\section{METODE PENELITIAN}

Pengumpulan data yang telah dilakukan sejak tahun 2001 meliputi survei dan ekskavasi. Pada tahun 2005 dilakukan ekskavasi dengan tata letak kotak gali dibuat secara systematic transect, sehingga diketahui luas situs (Tri Marhaeni 2005, 6). Analisis terhadap temuan artefak dilakukan dengan analisis khusus (bentuk, teknologi, stilistik) artefak dan analisis konteks dengan mengamati asosiasi, matriks dan keletakan artefak yang ditemukan dalam ekskavasi.

Analis ruang dilakukan dengan aplikasiSistem Informasi Geografis (SIG) atau Geographic Information System (GIS). Green (1990:5) menyatakan bahwa Sistem Informasi Geografis (SIG) merupakan salah satu solusi untuk mengatasi masalah-masalah keruangan dalam arkeologi. Sistem Informasi Geografis merupakan sistem informasi yang dapat memadukan data grafis dan database. SIG bereferensi terhadap koordinat di permukaan bumi yang diterapkan untuk mengelola informasi spasial (keruangan). SIG mempunyai kemampuan untuk mengolah data spasial dan atributnya serta mengintegrasi tipe data yang berbeda jenis tema maupun skalanya. Secara garis besar, SIG terdiri dari tiga subsistem, yaitu pemasukan (input) data, pemrosesan data, dan keluaran (output) data.

a. input data berupa data-data spasial (keruangan) yaitu data yang mempunyai acuan kebumian. Sumber data berupa peta analog (cetakan), foto udara, maupun citra digital.

b. Pemrosesan data meliputi pengelolaan, manipulasi dan analisis data spasial. Dalam pemrosesan ini data yang telah dimasukkan dapat dipanggil kembali untuk diperbaharui, ditambah, atau dikurangi informasi yang ada di dalamnya. Kemampuan SIG dalam analisis data spasial antara lain tumpang susun (overlay) peta, pembuatan peta jarak terhadap titik, garis dan bidang (poligon), transformasi koordinat, dan generalisasi obyek berdasarkan skalanya.

c. Output data SIG berupa cetakan (hardcopy), data tabuler atau dalam bentuk data spasial digital (softcopy). Hasil keluaran inilah yang digunakan oleh para pengguna sesuai dengan tujuan dan kebutuhannya..

Penggunaan SIG dalam kegiatan ini adalah untuk memetakan zonasi situs arkeologi di Karangagung Tengah dan sekitarnya. Dalam hal ini dibuat peta jarak (pemodelan jarak) dan tumpang susun peta (overlay).

a. Pemodelan jarak. Pembuatan peta jarak berdasarkan lokasi penemuan situs dan berdasarkan sungai lama yang berhasil diidentifikasi. Pembuatan peta jarak ini menggunakan fasilitas buffer yang ada dalam perangkat lunak SIG.

b. Peta jarak berdasarkan lokasi situs dibagi dalam 3 zona, yaitu zona 1 untuk jarak 0 - 500 meter, zona 2 untuk jarak 500-1000 meter, dan zona 3 untuk jarak 1000-1500 meter dari lokasi penemuan situs. Peta jarak berdasarkan sungai lama juga dibagi dalam 3 zona, yaitu zona 1 untuk jarak 0-200 meter, zona 2 untuk jarak 200- 
400 meter, dan zona 3 untuk jarak 400 - 600 meter dari sungai lama.

c. Tumpang susun peta (overlay) dilakukan dengan menggabungkan dua tema peta yaitu Peta Zonasi berdasarkan Situs dan Peta Zonasi berdasarkan sungai lama menjadi satu tema baru yaitu Peta Zonasi akhir yang berisi gabungan kedua tema tersebut. Proses tumpang susun peta ini mengacu pada matriks 2 dimensi yang sudah ditentukan sebagai berikut.

Tabel 1. Matriks zonasi situs

\begin{tabular}{|c|c|c|c|}
\hline \multirow{2}{*}{$\begin{array}{c}\text { Zonasi } \\
\text { Sungai lama }\end{array}$} & \multicolumn{3}{|c|}{ Zonasi Situs } \\
\hline & Zona 1 & Zona 2 & Zona 3 \\
\hline Zona 1 & 1 & 1 & 2 \\
\hline Zona 2 & 1 & 2 & 2 \\
\hline Zona 3 & 2 & 3 & 3 \\
\hline
\end{tabular}

\section{HASIL DAN PEMBAHASAN}

\section{Lingkungan Karangagung Tengah}

Wilayah Karangagung sekarang merupakan wilayah bermukim masyarakat transmigrasi yang mayoritas berasal dari pulau Jawa sejak 1983. Wilayah ini dibagi dalam tiga bagian, dari barat ke timur yaitu Karangagung Ulu, Karangagung Tengah dan Karangagung Ilir. Masing-masing wilayah tersebut terdiri atas sejumlah desa. Secara administratif Karangagung Ulu dan Karangagung Tengah masuk wilayah Kabupaten Musi Banyuasi, sedangkan Karangagung Ilir sebagian masuk Kabupaten Musi Banyuasin, sebagian masuk wilayah Kabupaten Banyuasin.

Wilayah Karangagung merupakan daerah rawa gambut dengan sungaisungai pasang surut yang berhubungan dengan Sungai Sembilang di bagian utara dan Sungai Lalan di bagian selatan. Sungai Sembilang merupakan sungai pasang surut yang memiliki pola aliran ranting (dendritik) yang bermuara di Selat Bangka. Sungai Lalan berhulu di daerah perbatasan Bayunglincir, Sumatera Selatan dan bermuara di Sungai Banyuasin. Sungai yang disebut belakangan ini juga bermuara di Selat Bangka.
Hampir seluruh daerah Karangagung Tengah terbentuk oleh endapan rawa dengan material berupa lumpur, lanau dan pasir. Endapan rawa itu meluas sampai ke tepi pantai. Pada beberapa lokasi di tepi Sungai Sembilang terdapat formasi Air Benakat dengan material berupa perselingan batulempung dengan serpih dan batulanau, bersisipan batupasir (Peta Geologi Palembang Lembar 1013). Daerah rawa dan pesisir di Sumatera Selatan memiliki gambut dalam, keanekaragaman hayati yang tinggi, mangrove pelindung pantai, bermacam hewan (Susanto 2010, 17).

Pendayagunaan lahan rawa oleh masyarakat tradisional cenderung tidak eksploitatif. Pada daerah tersebut terdapat kegiatan menangkap ikan tradisional, menyemaikan padi secara terapung, memelihara ikan dalam keramba di sungai, mendirikan rumah panggung di daerah genangan dan rumah terapung (rumah rakit) di tepi sungai (Susanto 2010, 18).

Sejak 1983 rawa pasang surut di wilayah Karangagung direklamasi untuk lahan transmigrasi. Sebagian Iahan digunakan untuk sawah, kebun kelapa, kelapa sawit. Reklamasi tersebut mengeringkan sungai dan rawa pasang surut sehingga melenyapkan sebagian besar ranting-ranting sungai, keanekaragaman hayati dan hewan, serta cara hidup masyakat tradisional dalam mendayagunakan lingkungan rawa.

\section{Permukiman Masa Pra Sriwijaya}

Berdasarkan hasil-hasil penelitian sebelumnya diketahui situs-situs permukiman pra Sriwijaya terdapat pada anak-anak sungai pasang surut yang kini tinggal jejak alurnya saja. Pola persebaran situs memanjang mengikuti alur sungai seperti yang tampak di Situs Karyamukti dan Mulyaagung. Alur sungai tersebut berhubungan dengan Sungai Lalan dan Sungai Sembilang.

Situs-situs lainnya tersebar di Purwoagung, Mulyajaya, Karangmukti dan Sukajadi berada pada anak-anak-anak sungai yang berbeda dengan anak sungai yang terdapat di Mulyaagung 


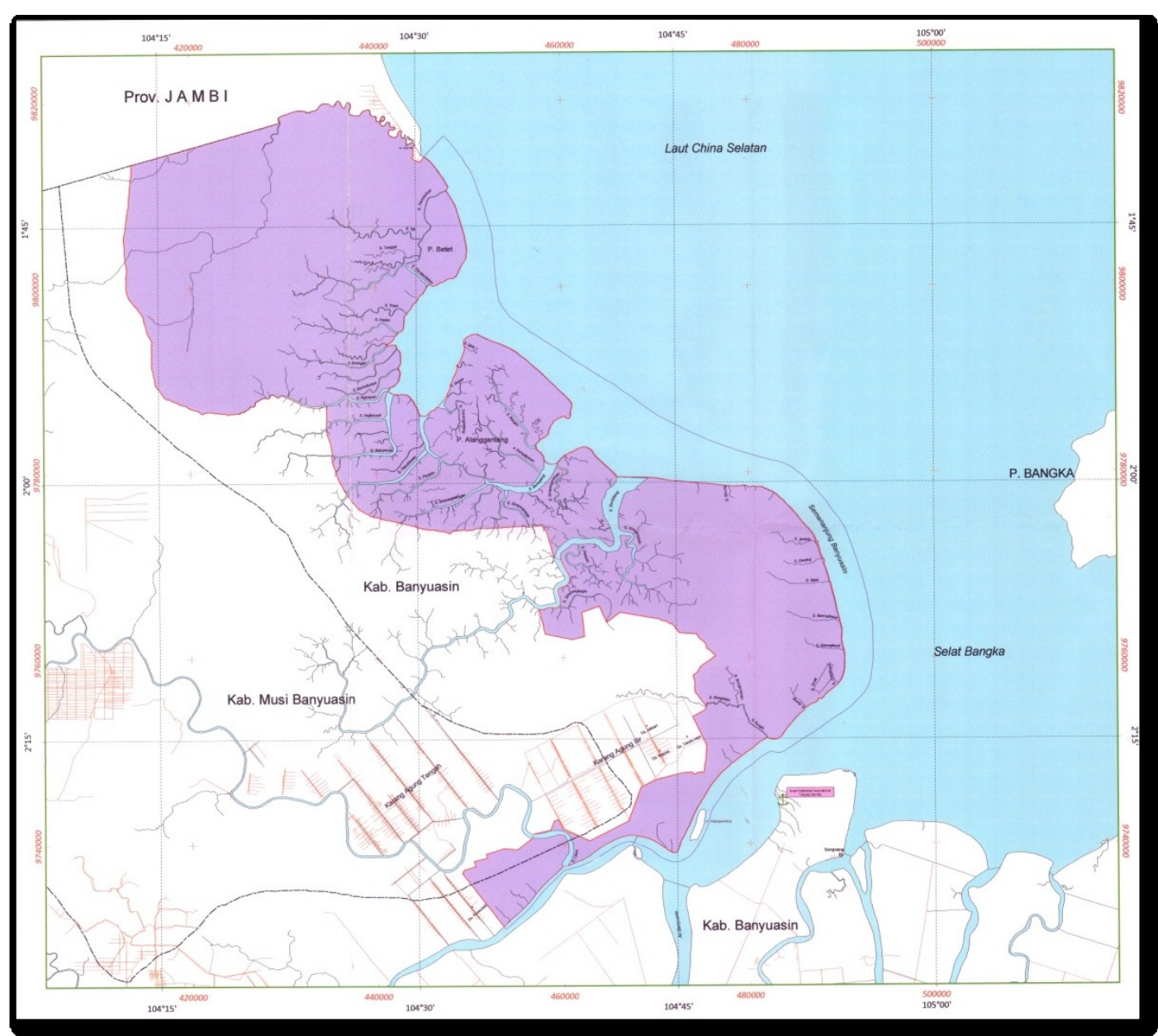

Gambar 1. Kawasan Karangagung Tengah

(Sumber: Taman Nasional Sembilang)

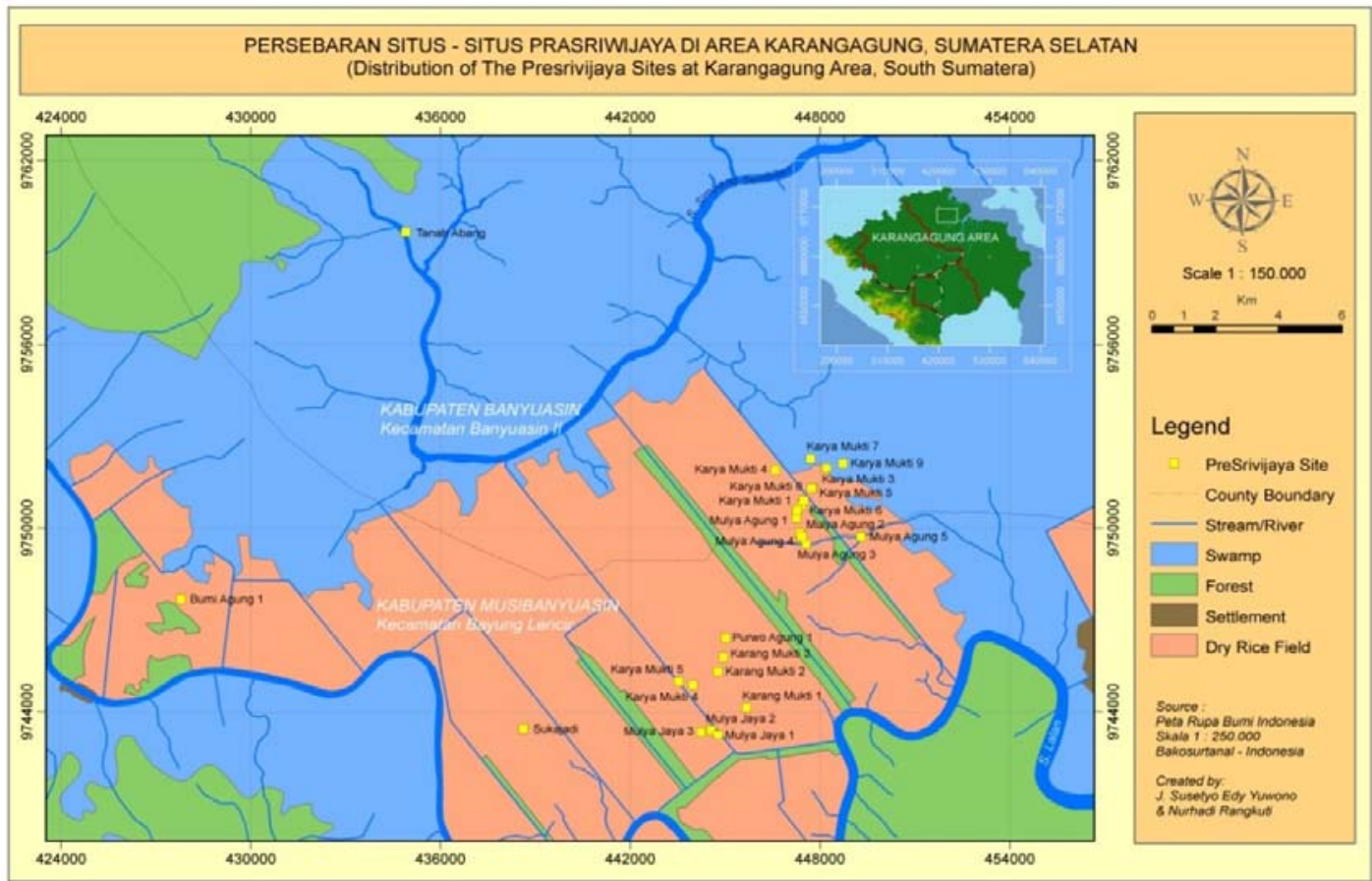

Gambar 2. Persebaran Situs Pra Sriwijaya di Karangagung Tengah (Sumber: Balai Arkeologi Palembang 2007) 
Situs-situs di Purwoagung dan Karangmukti berada pada satu alur sungai yang sama, yang ujungnya bertemu dengan Sungai Lalan. Situs Sukajadi (C) terletak pada anak sungai lainnya yang berhubungan dengan Sungai Sembilang. Sementara itu Situs Bumi Agung terpisah sendiri pada alur sungai yang berhubungan dengan sungai Lalan.

Persebaran situs tersebut terdapat pada ranting-ranting sungai yang berpola dendritik. Secara keseluruhan situs-situs di Kawasan Karangagung Tengah membentuk pola menyebar (lihat gambar 2 ).Persebaran situs tersebut selanjutnya dipetakan lagi dengan menentukan zonasi-zonasi, seperti yang tergambar pada peta-peta zonasi (lihat Gambar 3 dan Gambar 4)

\section{Faktor-faktor yang Berpengaruh Pada Permukiman di Rawa Pasang Surut}

\section{Dipilihnya kawasan Karangagung} Tengah sebagai permukiman masyarakat masa pra Sriwijaya perlu ditinjau dari berbagai faktor, Ada beberapa faktor yang dapat dipertimbangkan, antara lain faktor Selat Malaka dan Selat Bangka sebagai jalur perdagangan kuno, faktor ketersediaan sumber hayati dan faktor keamanan.

Berita Cina menyebutkan bahwa pada abad III-abad VII telah berlangsung hubungan perdagangan antara Cina dan nusantara. Tersebutlah Ko-ying, nama sebuah kerajaan nusantara bagian barat, yang menjadi pusat perdagangan yang penting pada pertengahan pertama abad III (Wolters 2011, 44-49). Ko-ying merupakan kerajaan yang sangat kuat, kerajaan orang barbar di selatan. Wilayah ini menghasilkan mutiara bergemerlapan, emas, zamrud, batu-batu kristal, dan juga buah pinang. Kemungkinan ada juga usaha pengumpulan hasil hutan setempat yang didorong kepentingan para pedagang India (Wolters 2011, 53). Wolters menempatkan lokasi kerajaan itu di pantai tenggara Sumatera. Bukti-bukti arkeologis dari abad II-IV yang terdapat di pantai tenggara Sumatera, antara lain di Kawasan Karangagung Tengah dan kawasan Air Sugihan, letaknya di bagian timur Karangagung Tengah.

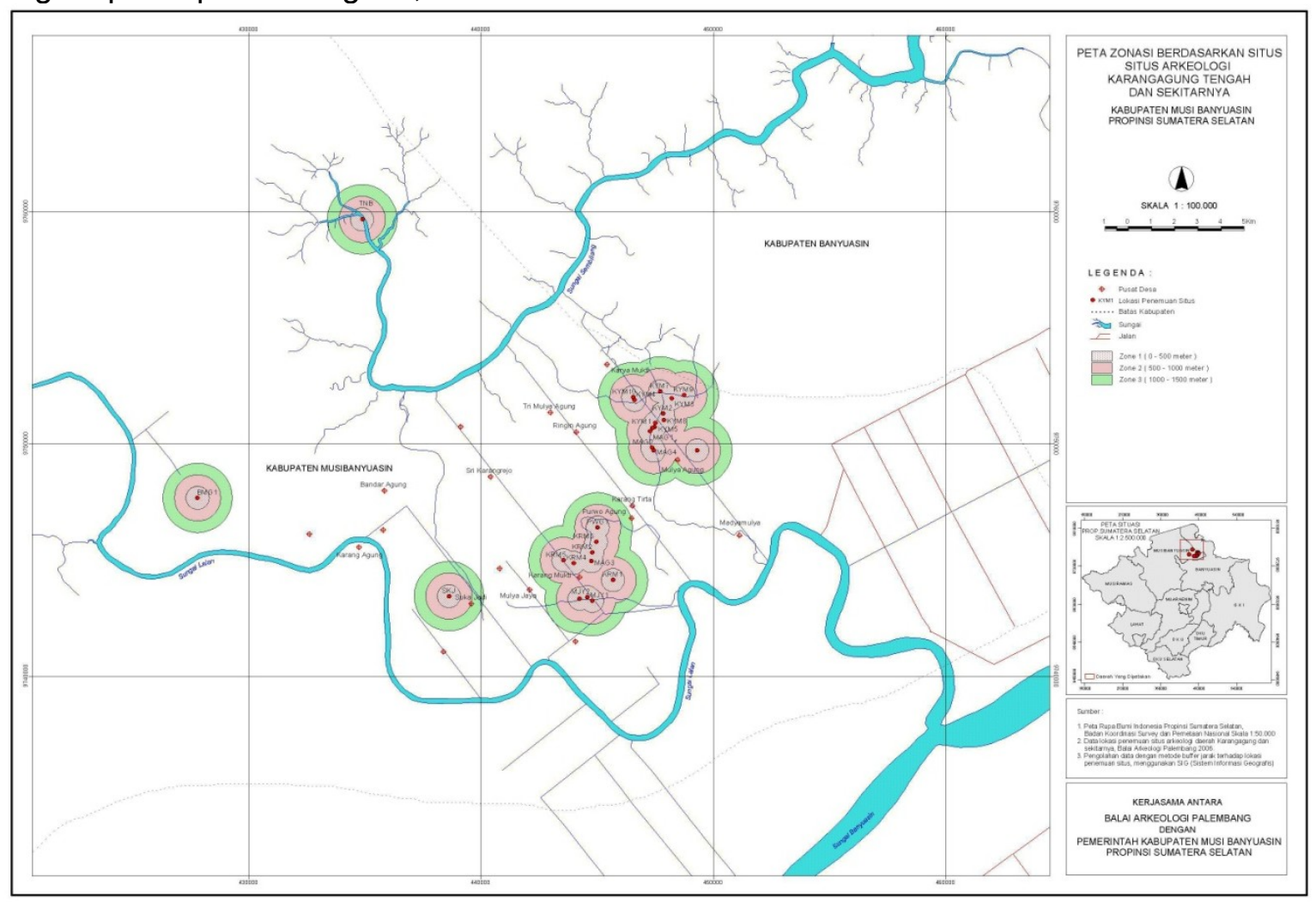

Gambar 3. Zonasi berdasarkan pengelompokan situs

(Sumber: Balai Arkeologi Palembang 2006) 


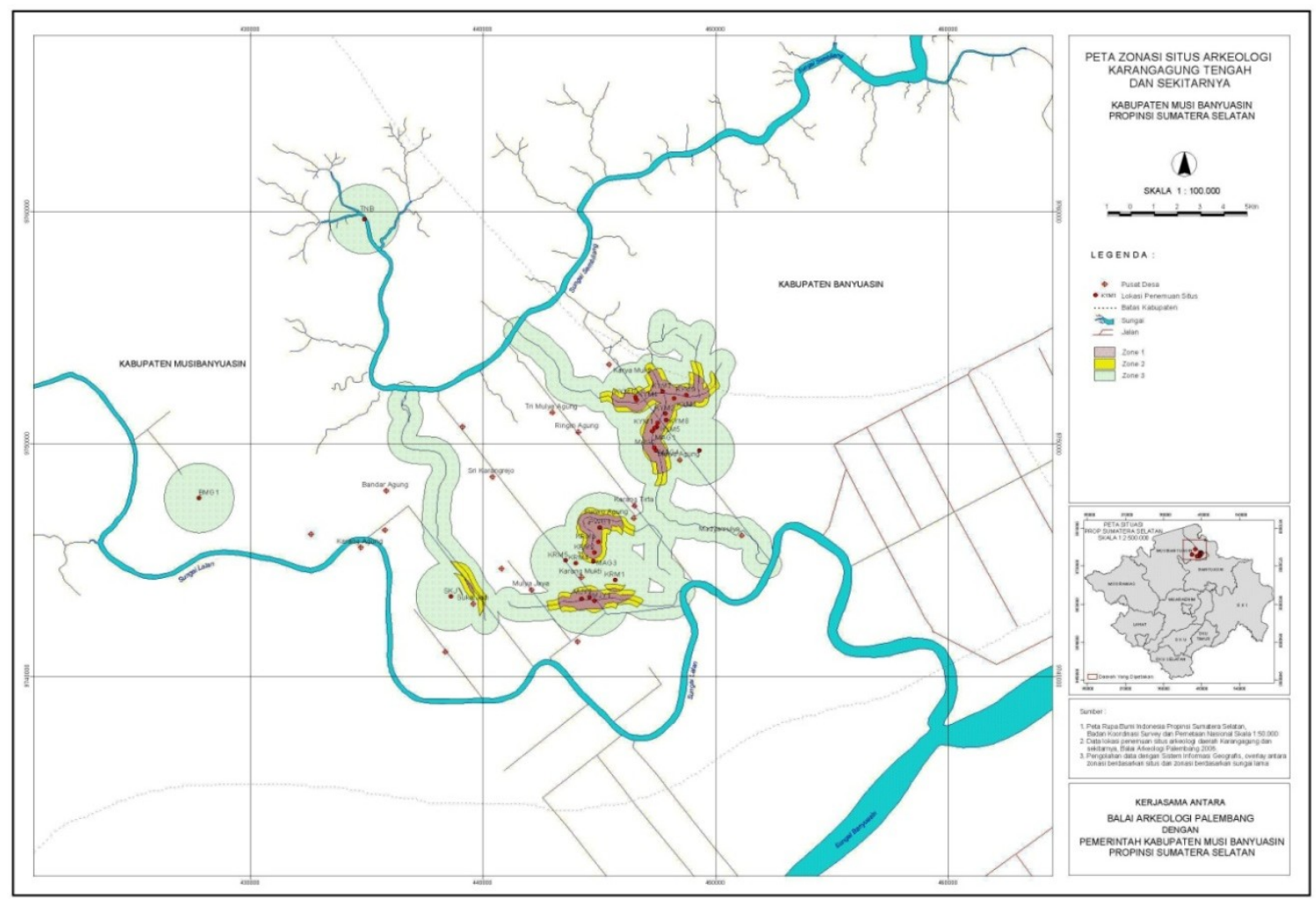

Gambar 4. Zonasi sungai berdasarkan pengelompokan situs (Sumber: Balai Arkeologi Palembang 2006)

Perbedaannya kawasan Air Sugihan menjadi daerah permukiman dalam waktu yang panjang, sejak awal Masehi sampai masa pasca Sriwijaya, sedangkan permukiman Karangagung Tengah ditinggalkan penduduknya sebelum abad V.

Pada pantai tenggara Sumatera terdapat jalan masuk melalui muaramuara sungai besar, yaitu Sungai Sembilang, Sungai Banyuasin, Sungai Musi, Sungai Saleh dan Sungai (Air) Sugihan. Kawasan Karangagung Tengah berada di hulu Sungai Sembilang dan di hilir Sungai Lalan yang bertemu dengan Sungai Banyuasin yang sangat lebar. Daerah bermukim di Karangagung Tengah lokasinya cukup strategis. Lokasinya terlindung dari gelombang laut dan serangan dari luar. Permukiman berada pada cabang-cabang sungai yang sempit sehingga kapal dan perahu ukuran cukup besar tidak dapat keluar masuk Karangagung Tengah pada saat air surut.

Pemilihan lokasi permukiman pada kondisi geografis semacam itu juga mempertimbangkan faktor aksesibilitas. Dari Sungai Sembilang mereka punya akses langsung ke pantai dan Selat Bangka, sedangkan dari Sungai Lalan mereka punya akses ke hulu dan pedalaman yang memiliki sumberdaya hutan dan sumber hayati lainnya untuk komoditi dan kebutuhan akan makanan.

Daerah Karangagung Tengah juga kaya dengan hasil hutan dan berbagai jenis hewan baik hewan darat maupun hewan yang hidup di air. Hasil hutan sebagian merupakan komoditi dagang dengan daerah lain. Salah satu komoditi dagang adalah temuan getah damar yang ditemukan dalam survei dan penggalian arkeologis.

Selain hal-hal tersebut, di sekitar Karangagung Tengah terdapat sumber air tawar, yaitu di Situs Tanah Abang di tepi Sungai Sembilang. Pada penelitian tahun 2010 dibuka satu kotak uji (testpit) di Situs Purwoagung. Di situs ini banyak ditemukan wadah-wadah gerabah berukuran besar, beberapa masih ditemukan utuh. Pada tahun 2010 dan 2014 sewaktu tim Balai Arkeologi Palembang melakukan survei di kawasan Taman Nasional Sembilang, penduduk menemukan wadah-wadah gerabah 
berukuran besar dalam kondisi utuh di Situs Purwoagung. Kemungkinan wadahwadah gerabah tersebut untuk menyimpan air yang diperoleh dari Tanah Abang pada saat kemarau dan untuk sumber hayati, faktor keamanan dan faktor tersedianya air tawar.

Kawasan Karangagung Tengah merupakan kawasan situs yang penting dari abad II-IV Masehi, sebagai salah satu kawasan permukiman pra Sriwijaya yang berada di rawa pasang surut. Kawasan ini dapat diusulkan sebagai kawasan Cagar Budaya dengan mengacu pada UndangUndang RI No 11 Tahun 2010 Tentang Cagar Budaya. Hasil penelitian yang antara lain berupa peta sebaran situs, dapat digunakan sebagai model delineasi kawasan cagar budaya yang pola sebarannya memanjang (linear) pada aluralur sungai yang bermuara pada dua sungai besar, yaitu Sungai Sembilang dan Sungai Lalan. Pelindungan terhadap situssitus di rawa pasang surut sudah saatnya dilakukan mengingat kawasan tersebut merupakan lahan-lahan milik penduduk transmigran yang aktif mengolah lahan untuk pertanian dan bangunan. Aktivitasaktivitas tersebut sering merusak cagar budaya. Selain itu penggalian liar untuk mencari artefak-artefak berharga seperti benda-benda dari emas dan batu mulia telah banyak yang hilang dan dijual kepada para penadah.

Upaya untuk menetapkan kawasan situs Karangagung Tengah sebagai Kawasan Cagar Budaya perlu melibatkan Pemerintah Kabupaten Musi Banyuasin. Dalam hal ini Bupati membentuk tim ahli Cagar Budaya untuk menetapkan kawasan Karangagung Tengah sebagai Kawasan Cagar Budaya. Dengan ditetapkannya kawasan tersebut dapat diprogramkan kegiatan pelindungan, pengembangan dan pemanfaatan Kawasan Cagar Budaya Karangagung Tengah. Pemanfaatan yang dapat diusulkan adalah untuk kepentingan penelitian, pendidikan dan pariwisata 


\section{DAFTAR PUSTAKA}

Bintarto, R. 1991. "Geografi Manusia: Teori, Tema dan Metodologi Penelitian" dalam Seminar Aplikasi Penelitian Geografi Untuk Perencanaan Pengembangan Wilayah, 29-31 Agustus 1991 di Fakultas Geografi Univ. Gadjah Mada.

1995. "Keterkaitan Manusia, Ruang dan Kebudayaan" dalam Berkala Arkeologi Edisi Khusus: Manusia dalam Ruang. Studi Kawasan dalam Arkeologi. Tahun XVEdisi Khusus 1995. Yogyakarta: Balai Arkeologi.

Clarke, David L (ed.) 1977. Spatial Archaeology. London: Academic Press

Kementerian Pendidikan Dan Kebudayaaan Republik Indonesia. 2012. Undang-Undang Republik Indonesia Nomor 11 Tahun 2010 Tentang Cagar Budaya. Jakarta: Direktorat Pelestarian Cagar Budaya dan Permuseuman

Green, Stanton W. 1990. "Approaching archaeological space: an introduction to the volume" dalam Kathleen MS Allea, Stanton W. Green (ed.) Interpreting Space: GIS And Archaeology. London-New York-Philadelphia: Taylor and Francis. HIm. 1-8.

Rangkuti, Nurhadi. 1996 "Aplikasi Sistem Informasi Geografis Dalam Penelitian Arkeologi Skala Wilayah" dalam Jurnal Penelitian Arkeologi no.04 II/1996. Yogyakarta: Balai Arkeologi. HIm 63-68.

Sutanto, Robiyanto Hendro. 2010. Strategi Pengelolaan Rawa Untuk Pembangunan Pertanian Berkelanjutan. Palembang: Jurusan Tanah Fakultas Pertanian Universitas Sriwijaya.

Tri Marhaeni dan S. Budi Santosa. 2005. "Pemukiman Pra Sriwijaya di Pantai Timur Sumatera Kawasan Karangagung Tengah Kabupaten Musi Banyuasin Provinsi Sumatera Selatan" dalam Berita Penelitian Arkeologi No.13. Palembang: Balai Arkeologi.

Vink, A.P.A. 1983. Landscape Archaeology and Land Use. London-New York: Longman.

Willey, Gordon R. 1953. Prehistoric Settlement Pattern in the Viru Valley. Peru: V.S.

Wolters. O.W. 2011. Kemaharajaan Maritim Sriwijaya di Perniagaan Dunia Abad III-Abad VII. Jakarta: Komunitas Bambu.

Yuwono, Susetyo Edy, 2007 "Kontribusi Aplikasi Sistem Informasi Geografis (SIG) Dalam Berbagai Skala Kajian Arkeologi Lansekap" dalam Berkala Arkeologi Th XXVII Edisi No 2/November 2007. Yogyakarta: Balai Arkeologi. HIm 81-102. 